doi: 10.15503/jecs2021.1.520.529

\title{
GEORGIAN EXPERIENCE IN THE FIELD OF EDUCATION AND CULTURAL POLICY: THE EXAMPLE OF THE FIRST DEMOCRATIC REPUBLIC OF GEORGIA IN THE YEARS 1918-1921
}

\author{
MANANA DARCHASHVILI \\ Georgian Technical University \\ 77, Kostava str., 0160, Tbilisi, Georgia \\ E-mail address: mananadarchashvili@gmail.com \\ ORCID: https://orcid.org/0000-0002-7414-5160
}

\begin{abstract}
Aim. The paper aims to explore the issue of Georgian education by analysing it chronologically and thematically and recalling past experiences. The paper focuses on the period of the First Republic of Georgia, 1918-1921, and highlights the place of education and culture in Georgian politics. Moreover, the paper considers the connections of modern Georgian politics and the centuries-old traditional heritage and its transformation in the present reality.

Method. The paper is presented based on a number of studied documents, empirical materials, scientific research papers, monographs. The study comprises analysis of government documents and historical-comparative method.

Results and Conclusion. The empirical materials prove that, despite the difficult political situation, during the period of the First Republic of Georgia (1918-1921), education in Georgia was well developed, which occurred with the support of the government and due to the active and creative work of representatives of such fields as education, literature, theatre, music, cinema, and science. Thus, the paper presents the reality of the first democratic republic of Georgia during 1918-1921, it appears so that the certain reforms conducted by the state in the past in field of education and cultural policy are very important even in the modern days.

Key words: Georgia, culture, education, politics, state.
\end{abstract}

\section{INTRODUCTION}

Since the declaration of state independence in Georgia, the main ruling $\checkmark$ political party, i.e. the Social Democrats, has faced many problems rooted in the current reality (difficult domestic and foreign situation in the country). The party was responsible for providing the citizens of the country with very tough economic conditions. However, the collective desire to create a democratic republic based on high values and advanced ideas was deep. The First 
Republic of Georgia, in a very short period of its existence, managed to provide a certain experience of democratic development, which is important from the state-political point of view.

Education and culture are strategically important and promising areas for the state. Sustainable development of the country is practically impossible without them. Therefore, the mentioned areas have always been presented the main priority goals of the country's authorities. At the same time, Georgia remains a country where education and culture are still understood as the most important preconditions for the country's economy and even social development. After the restoration of Georgia's state independence in 1991, many country-based scholars became interested in studying the education and cultural policy of the First Democratic Republic of Georgia (1918-1921). The assessment and comprehension of the rather rich experience of the past are highly useful for the country's modern reality. The interest in the First Democratic Republic of Georgia has been particularly intense on the occasion of the 100th anniversary of Georgia's state independence in 2018. Many interesting works have been published, which state that the restoration and proclamation of Georgia's independence was not only a political and historical act but that it also became a platform for the beginning of new education and cultural life and the embodiment of creative ideas.

Due to several implemented reforms, modern cultural systems of education and science have significantly progressed. After the restoration of Georgia's state independence in 1991, reforms were aimed at creating new systems compatible with rapidly changing world requirements, and at establishing the country in a competitive environment at the international level.

In general, Georgian culture is distinguished by its originality and historical traditions; the country's society always shared its cultural elements and values. At the same time, activities in the field of culture are based on the prevailing opinion that development cannot be sustainable without a strong cultural component. We have to highlight that Georgia is a multicultural state, where ethnos and cultural groups with different ethnic or religious characteristics traditionally live together, which is considered an important feature of the country's culture.

Georgian unique cultural treasures are constantly updated with the ability to self-renew, giving a chance to a rich creative potential. The development of the present based on the past is the most important for the country and a precondition for the well-being of the society.

Prioritisation of education in Georgia is also based on an ancient tradition. Therefore, taking care of the compliance of modern education programmes with the current and future demands of the labour market. At the present stage, the four-point plan of reforms implemented by the Government of Georgia has given priority to education, which will ensure the development of human capital and its effective involvement in the country's evolution.

The country's strategic education priorities include such issues as the specific educational programmes in various fields that aim to strengthen national, social, and cultural characteristics and as well as to encourage the development 
of citizenship in the country. Despite existing measures, a number of challenges to the quality of education and equal access remain. Therefore, the government of all times is trying to improve the existing situation based on past experience, which counts 100 years of history, starting directly from the colonial regime. It is worth saying that for the first time in the European space, it relevant to study the agenda of education and culture during the period of the Social Democratic Republic of Georgia. The time seems particularly relevant as in 2021 Georgia celebrates an anniversary: 100 years ago, the Democratic Republic of Georgia adopted its Constitution. Therefore, the country needs to realise and understand the current reality, consider the necessity of planned local changes, and perceive the agenda of such important directions for the country as the international integration.

\section{GEORGIAN EXPERIENCE IN THE FIELD OF EDUCATION POLI- CY ON THE EXAMPLE OF THE FIRST DEMOCRATIC REPUBLIC OF GEORGIA (1918-1921)}

Georgia declared its independence on May 26, 1918, when, after a long period of absence of state identity in Georgia, the Democratic Republic of Georgia with a modern political system was formed (Matsaberidze, 2019); before that, Georgia was a part of the Russian Empire for 117 years. In the Georgian reality, the representatives of the political parties have repeatedly discussed what kind of republic was necessary to establish a high degree of democracy in the country. The decision was as follows - the Republic without a president; with one chamber, i.e. the legislative body called the Parliament elected by universal, equal, direct, and secret ballot; the executive body, namely the Government of Georgia; and an independent judiciary system (Arsenidze, 2014).

A number of documents confirm the desire and willingness of the politicians who came to power to create a democratic republic. Before the declaration of state independence, the country was well aware of the demand to regulate the issue of national education, which is evident in the statement of Ilia Chavchavadze, a prominent Georgian writer. He stated that not only the fate of the next generation depends on the good conduct of education, but also the future of the country belongs to the youth and, therefore, the future of the country creates the fate of the country itself. At the same time, he noted that the country needs European experience, science, and education, which should be the country's weapon (Chavchavadze, 1887). Therefore, initially, the coalition government also comprised the position of Minister of Public Education, which was assumed by the Socialist-Federalist Giorgi Laskhishvili.

At the modern stage, when we start discussing educational and cultural policy, there is an interest in how the issue was raised and discussed in the main legal documents existing at that time. In this regard, we have to highlight the approach of the first Constitution of Georgia. 
Chapter 12 of the Constitution of Georgia, which mentioned education and art, was named "Education and School" and included four articles from 109 to 112. Particularly, it stated that art, science, and their teaching were free: that it was the duty of the state to protect and promote their development; that primary education was universal, free, and compulsory; and that the public school system was a single organic unit, where the primary school was the basis of the secondary and high school. Moreover, it said that the education was secular in schools of all levels; the state aimed to provide food, clothing, and school supplies to the poorest children in primary school free of charge, with the state and local governments having to allocate funds from the budget each year; and private schools had to obey the common school law. The constitutional approach to education was truly democratic and development-oriented. However, unfortunately, the constitution, which was adopted on February 21, 1921, was in force only for 4 days, after which Georgia was Sovietized (Constituent Assembly of Georgia, 1921).

It is important to note that by that time the first National University in the Caucasus had already been established in Georgia on January 26, 1918 (February 8 in a new calendar). Ivane Javakhishvili, the founder of the university, was initially appointed the dean of the Faculty of Theology, and on December 17, 1919, he was promoted to the position of rector.

The authorities were well aware of his merits, scientific achievements, and opportunities, therefore he was actively involved in the state-building of the Democratic Republic of Georgia, in particular, in parallel with his scientific work. By the proposal of the National Council of Georgia, together with socalled 'noblemen', he participated in the development of the national flag and state coat of arms (Janelidze, 2018).

By the Law of the National Council of Georgia and the Republic of Georgia of September 3, 1918 "On Declaring the Georgian University a State University" the following was enacted: 1) Georgian University was declared a state university and renamed "Tbilisi State University," 2) a certain amount was included in the annual expenses of the state for the maintenance of the university; 3) a preliminary basic provision of the University was approved, in which all the details were intended for the full functioning of the University and provided for its autonomy as the property was transferred to the University by the state. On the other hand, the university was responsible to the Ministry of Public Education and the educational process at the university had to be conducted in Georgian, however certain exceptions were allowed. It was required that the post of professors and associate professors at the university could be occupied only by a person holding a master's or doctoral degree from a foreign university. At the same time, the diploma and dissertation should have been reviewed by the relevant faculty. Dissertation defence was rare in Tbilisi at that time; only two dissertations were defended within the period of 1918-1921 (Songulashvili, 2016).

According to the same law, the Queen Tamar Women's Seminary of the Education Society was declared a state school and transferred to the government board (Sharashenidze, 1990). The law of September 13 also declared the 
Tbilisi Vocational Institute, Gori, Khoni, and Sokhumi seminaries as Georgian state schools. The Abkhazian university branch was opened near the Sokhumi seminary.

It should be noted that the law of October 1, 1918, the Georgian language as the state language since the use of the language of the national minority was determined by a separate law (Kobakhidze, Silagadze, Vacharadze, \& 2018).

In the Social Democratic Republic of Georgia, it became necessary to discuss the issue of teaching the divine law, which was determined by the democratic approach of the National Council of Georgia and the Law of the Republic of Georgia dated November 26, 1918, before the adoption of the Constitution. Theology teaching was abolished in public and private schools of all types and at all levels, and the position of subject teachers who had been awarded the prize established by the law of July 5,1918 , which provided benefits to dismissed employees, was abolished. Besides, if someone wanted to study theology, they could do so in the school building, but in a way that would not interfere with other subjects in time and covering all the costs with their own financial resources. This approach is fully consistent with the lifestyle of modern secular states more than a century later. As for the schools of national minorities, non-Georgian schools did not comply with this law, which means that their students had religion classes (Janelidze, 2018).

The issue of the Georgian language and the establishment of literary norms were important and required attention at that time, to which the Education Committee under the Ministry of Education, headed by Ivane Javakhishvili since February 1920, made a great contribution (Chumburidze, 2000).

The establishment of a Sanitary Institute at Tbilisi State University was of great importance throughout the country. According to the law adopted on January 18, 1919, Tbilisi Sanitary Institute, a state medical institution that was under the Ministry of Education, was subordinated to Tbilisi State University. The Military Medical Laboratory, the Pasteur Station, the Chemical and Bacteriological Laboratories of the Medical Board, and the Malaria Station started to operate within the frame of the Sanitary Institute (Sharashenidze, 1990).

By the law of June 20,1919, the government arranged summer courses for the training of primary school teachers. A special amount was allocated from the treasury to the Ministry of Education to organise these courses for 250 teachers of public schools.

It is no surprise that nowadays the government follows its past experience and actively impliments it at the currect stage. Particularly, it aims to develop the education system in the direction of fostering its inclusion in the international educational space.

In this regard, it is worth highlighting the special programme "Learn in Georgia," operating within the framework of the Ministry of Education and Science of Georgia, with the support of the Ministry of Foreign Affairs of Georgia, which launched an information campaign to attract foreign students. As a result, many students became interested in Georgian higher education institutions through international educational exhibitions. Another success of Geor- 
gian education is visible in the functioning of the newly established Kutaisi University Complex. The University has wide foreign ties and a particularly relevant international agreement has been signed, according to which the Munich International Technical University (TUM International), together with the Georgian side, has developed cooperation at all stages of the development of the Kutaisi University Complex. The Georgian government has been working for many years to integrate the universities operating in the country into the world university rankings system.

\section{GEORGIAN EXPERIENCE IN THE FIELD OF CULTURAL POLICY ON THE EXAMPLE OF THE FIRST DEMOCRATIC REPUBLIC OF GEORGIA (1918-1921)}

At the beginning of the 20th century, despite the difficult and turbulent socio-political situation in Georgia, the major consideration for and the development of cultural issues occurred. The cultural cooperation of the Georgian people with others is present in many primary sources, which is reflected by the Georgian press of that time (Darchashvili, 2013).

In the times of the First Republic of Georgia, cultural issues were subordinated to the Ministry of Public Education with no separate ministry established. However, since 1919, there has been an art commission in the Constituent Assembly along with other commissions.

During the three years' existence of the Democratic Republic, the country's art workers, supported by the government, had their impact on almost every field of art: literature, theatre, music, film, or painting. Great traditions continued in the countr museum life in Georgia and numerous artistic and literary associations were established, which played an important role in cultural life.

It is worth mentioning that by the decree of March 30, 1920, the National Art Gallery of Georgia was established. Despite financial difficulties, the state strongly encouraged various artistic initiatives and provided material assistance, which is evidenced by sending the Georgian artists to study abroad or the opening of numerous exhibitions. In 1919, the foundation was even laid for a travelling art exhibition.

It is noteworthy that in the Democratic Republic charitable evenings were held and the spouses of politicians actively participated in the organisation of musical events.

In the press from that period, posters, reviews, and letters of thanks were systematically printed for theatrical art lovers. The population actively attended various theatrical performances (Chanturidze, 2018).

The cultural policy of any country is motivated by the preservation, protection, and development of its cultural heritage. Accordingly, it was a great importance for the Georgian reality that by 1918 the museums in Georgia had been successfully operating. Founded in 1852, the Caucasus Museum was transformed into a Georgian museum in 1919, continuing the old traditions. A 
large part of the Georgian cultural heritage was stored there, together with the intellectual and scientific potentialImportantly, according to the law of August 1, 1919, the purpose of the Georgian Museum was to facilitate the scientific study of Georgia. For the museum had to arrange, organise, preserve and scientifically process every material and collection related to Georgia's physical nature, ethnography, history or archaeology. The museum pursued research in different areas, owned bookstores and issued periodicals.

In 1918-1921, Georgian cinematography already had some experience; Vasil Amashukeli had already shot documentaries (1908) and films (1912). In 1918, Germane Gogitidze made the first Georgian feature film Christine, whose author and director was A. Tsutsunava, who was perceived as the pioneer of the Georgian documentaries (Makharadze, 2012). Since then, there had been filmed several short documentaries. In this regard, the film material of the chronicles recorded by Germane Gogitidze "May 26, 1919" and "May 26, 1920" is noteworthy as it is a documentary footage of the celebration of Independence Day during the First Republic of Georgia (Gogitidze, 2013). Georgian cinema was founded in September 1919 and since then it has been operating as a public organisation. It should be noted that there were more than twenty cinemas in Georgia in 1918-1921, where many foreign films such as American, Italian, French, German, and Russian were shown. The Georgian authorities were well aware of the need to ban the export of historical, archaeological, artistic, and other cult objects from the Republic of Georgia. The ban was enacted by a decree passed on May 28, 1920. The banned objects included all sorts of artefacts from all the ancient archaeological excavations, various old items including those related to art, as well as household items, books, manuscripts, and other antiquities of any cognitive significance.

By the law on the National Council of Georgia and the Republic of Georgia dated December 13, 1918, it was determined that the Minister of Agriculture was entitled to confiscate agricultural land of cultural significance.

During the years of independence, the cooperation of Georgian politicians with foreigners in various directions was very vital. It is noteworthy that the German-Georgian cultural society was brought to life in July 1918 to establish ties between the two nations, bringing their cultures closer and creating cultural dialogue. Ivane Javakhishvili was a member of this society, which along with other similar organisations served to better understand the European factor in the population of Georgia, to support and to strengthen the western orientation of the country.

It is important that in the period of the First Republic, there were published many magazines and newspapers emphasising education and culture, both locally and internationally. The time period after 1918 was a short but wonderful epoch for the culture of Georgia. Tbilisi became an important and famous centre of modernism and avant-garde. Active development of every cultural sphere, such as literature or painting occurred; cooperation, mutual recognition, and respect for local creativity and foreign celebrities were present (Shvelidze, 2018). 
In fact, with the support of the government in the field of education and culture, various Georgian specialists were actively engaged in creative relations with their neighbours, as well as with different people of the world. Georgian intellectuals and self-active political figures supported any new initiative of other people in the field of culture and education and tried to develop creative relations peacefully. No less important is the fact that during that period Georgia was proud of its multi-party and multi-profile press, created by the unprecedented pluralistic environment characterizing the journalism of the independent country and reflecting its epoch with dignity.

As in the past, one of the current priorities of the Georgian government regarding the implementation of cultural policy is the protection of cultural heritage, rehabilitation and conservation of a number of cultural heritage sites, for which several projects have been implemented.

It should be highlighted that Georgia has been a full member of UNESCO since 1992. During the many years of cooperation, numerous important projects have been implemented in Georgia with the funding of UNESCO, the aim of which is to protect archaeological monuments, museum collections, intangible heritage, and other forms of culture. The state also supports innovation and creativity in various fields of culture. Great attention is paid to include new Georgian sights and traditions on the UNESCO.

Important projects for the rehabilitation of cultural infrastructure are being implemented. It is worth mentioning at this point the rehabilitation of various theatres, art academies, and other buildings; moreover, the promotion of museums has become a top priority issue. For this purpose, a unified centralised system of electronic registration of museum exibits was developed. Moreover, numerous cultural cooperation programmes have been signed between the governments. Besides, an unprecedented increase in international funding is noteworthy as, within the framework of the Creative Europe programme, many projects have received funding. Thus, Georgia has become the 27th member of the Cultural Routes Programme, paving the way for the country to enter the international tourism arena.

In order to popularise Georgian culture, international traditional festivals are held yearly in the country, including international festivals of books, literature, theatre, visual arts, international music festivals and symposia, international folklore festivals, exhibitions of traditional handicrafts, etc. In this regard, the participation of Georgian artists in important events both in Georgia and abroad should be emphasised as well.

To promote the development of art education, a certain number of students continue their studies in foreign art-educational institutions with the support of the government. In this case, it is worth mentioning that they are also actively involved in competitions, festivals, internships, and advanced training courses to fulfil the main task of increasing the value of culture and creativity in the country's economy through the development of creative industries in connection with culture and other creative fields. 


\section{CONCLUSION}

During the period of the First Republic of Georgia (1918-1921), the cultural politics in Georgia was considered vital; it was well-developed and gave a possibility to establish a solid educational system and develop relations with many foreign countries.

Many facts prove that the Georgian intellectuals together with the government accepted all the responsibility and did their best to form an independent Georgian education system, to develop national culture, and to establish a proper, dignified place in the developed, civilised world.

It emerges from this paper that the past and present approaches are similar on many issues, meaning that the past and the present Georgian governments have been actively considering the issue of separating the Ministry of Culture from the Ministry of Education, Science, Culture, and Sports.

For modernity, it may seem that these are just ordinary issues. However, it should be underlined that, despite the lack of experience even a century ago, the country's educational and cultural policy was implemented by sophisticated politicians and intellectuals, who were following modern democratic standards and actions. We could claim that if not for the decades-long Soviet regime's interference, which destroyed every sphere in the country and introduced a limited ideology of education and culture, the existing modern systems developed in the past would be at a much higher level today.

\section{RECOMMENDATIONS}

The studied materials show that the education and culture policy pursued by the state during the First Democratic Republic of Georgia (1918-1921) left significant traces. Consequently, the policies pursued in the past are a remarkable, important achievement and accountable to modernity.

\section{REFERENCES}

[1] Arsenidze, R. (2014). The Democratic Republic. Tbilisi: Davit Batonishvili Institute of Law.

[2] Chavchavadze, I. (1887). Education is the Prerequisite for the Nation's Success. Tbilisi: Newspaper Iveria.

[3] Chumburidze, D. (2000). Education 1918-1921. Tbilisi: Universal Publishing House.

[4] Chanturidze, S. (2018). Cultural chronicles of the Democratic Republic of Georgia (1918-1921). Tbilisi: Ivane Javakhishvili Tbilisi State University.

[5] Constituent Assembly of Georgia. (1921). Constitution of Georgia. Adopted by the Constituent Assembly of Georgia on February 21, 1921. Retrieved November 10, 2020, from https:// www.matsne.gov.ge/ka/document/view/4801430?publication $=0$

[6] Darchashvili, M. (2013). Georgian Socio-Political Opinion on Interethnic Relations in the Georgian Democratic Press (1900-1917). Tbilisi: Universal Publishing House.

[7] Gogoitidze, G. (2013) From the Past of Georgian Cinema. Tbilisi: Saga Publishing House.

[8] Janelidze, O. (2018). Essays on the History of the Democratic Republic of Georgia (p. 58). Tbilisi: National Parliamentary Library of Georgia.

[9] Janelidze, O. (2018). In the Footsteps of Ivane Javakhishvili (p. 32). Tbilisi: National Parliamentary 
Library.

[10] Kobakhidze, B., Silagadze, D., \& Vacharadze, A. (2018). The First Republic of Georgia. Tbilisi: Ministry of Justice of Georgia and National Archives of Georgia.

[11] Makharadze, I. (2014), The Great Mute History of Georgian Cinema. Tbilisi: Sulakauri Publishing House.

[12] Matsaberidze, M. (2019). Georgian Political System (p. 230). Tbilisi: Ivane Javakhishvili Tbilisi State University.

[13] Neparidze, T. (2018). 100 Years of Independence towards Freedom. Tbilisi: Institute of Education and Awareness.

[14] Shvelidze, D. (2018). Democratic Republic of Georgia (1918-1921). Encyclopedia-Dictionary. Tbilisi: Ivane Javakhishvili Tbilisi State University.

[15] Sharashenidze, V. (1990). Collection of Legal Acts of the Democratic Republic of Georgia 1918-1921. Tbilisi: Georgian Society of Knowledge.

[16] Songhulashvili, A. (2016). History and Modernity. Tbilisi: Universal Publishing House. 